\title{
The Acceptance of Mobile Learning: A Case Study of 3D Simulation Android App for Learning Physics
}

\author{
https://doi.org/10.3991/ijim.v15i17.23731 \\ Lisana Lisana $^{(\varpi)}$, Marcellinus Ferdinand Suciadi \\ University of Surabaya, Surabaya, Indonesia \\ lisana@staff.ubaya.ac.id
}

\begin{abstract}
This study explores the determinants that influence the acceptance of mobile learning, with a case study of a 3D simulation Android app, as an innovative tool for learning physics for high school students. The research model is developed based on prior studies in mobile learning acceptance, where Perceived Usefulness and Perceived Ease of Use are the two most popular determinants, with the addition of Perceived Enjoyment. Data are collected through questionnaires distributed to 50 high school students using Google Form. This study uses the structural equation modeling (SEM) technique to conduct the final analysis. The findings confirm that Perceived Enjoyment becomes the most influencing factor considered by high school students to use mobile learning, 3D simulation Android app, followed by Perceived Usefulness. However, the Perceived Ease of Use is an insignificant predictor that influences the acceptance of the 3D simulation Android app.
\end{abstract}

Keywords-m-learning, 3D-simulation, android

\section{Introduction}

Nowadays, mobile devices seem to become an inseparable part of human life. Mobile technology with internet connectivity has been evolved and increased convenience for its users due to its diverse functionality. A survey reported that in January 2021, there were 202.6 million ( $73.7 \%$ of the total population) internet users in Indonesia [1]. Furthermore, 96 percent of the internet users in Indonesia were using mobile phones [2]. Therefore, Indonesia has become one of the fastest-growing mobile app markets globally. Indonesian publishers had produced 47,573 mobile apps, which are prioritized on apps rather than game development, with the percentage of app and games are $89 \%$ and $11 \%$, respectively [3].

The mobile phone functionalities are not only for communication but also for learning purposes, commonly referred to as mobile learning (m-learning). Mobile phones have become an essential device to create innovative learning methods, self-exploratory learning outside the classroom, problem-solving, and enhancing student's academic performance [4]. A recent study showed that incorporating multimedia and use of 
touchscreens on mobile phones into learning can be performed to as early as kindergarten and primary school students to enhance their skills in an engaging environment, as well as increasing their motivation on the subject, compared to traditional teaching methods [5]. Thus, m-learning becomes an essential part of academic society. During the Covid-19 pandemic, students or learners have to switch their learning method from face-to-face to online learning using mobile devices as the main tools.

As a part of m-learning, mobile app usage has also been investigated as an innovative tool to achieve the student's cognitive level in physics learning [6]. The high school students can be categorized as Generation Z (Gen Z), that prefer to use the mobile phone to perform their daily activities [7]. Furthermore, Gen $Z$ students are more attracted to multimedia, especially $3 \mathrm{D}$ simulation, when they learn something. This condition might happen because they are raised in a technology-savvy environment [8]. A prior study also argued that 3D simulation could produce a powerful immersive environment so learners can gain knowledge and create higher-level thinking skills [9]. Unfortunately, the adoption of m-learning in education is still considered slow [10]. There are also limited studies in m-learning acceptance that focused on the usage of 3D simulation mobile app. A literature review study conducted by Reisoğlu et al. found that the percentage of research in using the $3 \mathrm{D}$ virtual learning environment in science subjects is still less than ten percent [11].

Therefore, this study is expected to fill this gap by investigating the determinants that influence high school student's intention to adopt m-learning, specifically a 3D simulation Android app. The application is developed to create student's understanding of the concept in physics. The results provide the theoretical contribution due to the limited studies that explored the factors that significantly affect the adoption of 3D simulation mobile app in the education field, especially in science subjects. Furthermore, the findings can be used by mobile application developers as a guideline to develop a successful mobile app, especially in education fields using 3D technology.

\section{Literature review}

There are various definitions related to m-learning. In general, m-learning combines mobility with the electronic learning (e-learning) concept. Wang et al. [12] defined m-learning as using mobile devices to deliver learning materials to learners through wireless internet anytime, anywhere. Crompton [13] referred to m-learning in terms of accessibility and flexibility since learners can learn across multiple contexts using their personalized electronic devices. In this study, the definition of m-learning refers to student's ability to perform learning activities anytime, anywhere using their internet-enabled mobile devices through wireless technology.

The research in m-learning has increased in the last decade since the emergence of smartphones and other internet-enabled mobile devices. Mobile technology has supported the strategic goals in the education field by enhancing student's participation and achievements and improving the collaboration and interaction among students [14]. Some authors had examined the factors that influence m-learning adoption among students in various countries such as New Zealand [15], China [16], Jordan [17], and Sweden [18]. A study conducted in Greece showed that preschool teachers generally 
welcome ICT usage, particularly m-learning, in their daily teaching, regardless of age and gender [19].

One popular model in adopting new innovative technology is TAM (Technology Acceptance Model), proposed by Davis [20]. TAM suggested two variables, Perceived Usefulness and Perceived Ease of Use, which determined the attitude toward using technology that affects the Behavioral Intention. Many prior studies used TAM in their theoretical model to explore user acceptance of m-learning [17], [21]. Several authors used extended TAM in their theoretical model by adding some essential determinants to increase the explanatory power of the research. Some studies confirmed that Perceived Enjoyment was another crucial predictor that significantly influences m-learning adoption [9], [22].

\section{Methodology}

This study is a quantitative research that uses a cross-sectional survey to obtain data based on the individual's experience using a 3D simulation Android app. A two-part self-administered questionnaire is then developed based on prior studies to maintain the content validity. The first part is related to the respondent's characteristics (age, gender, and education). The second part contains questions associate with each variable used in the research model. The instruments are adopted from the existing studies in m-learning adoption measured using a 5-point Likert scale, ranging the options from Strongly Disagree to Strongly Agree. The measuring instruments are listed in Table 1.

Table 1. Instruments of Variables

\begin{tabular}{|c|c|}
\hline Variable [Ref] & Measuring instrument \\
\hline \multirow{4}{*}{$\begin{array}{l}\text { Perceived } \\
\text { Usefulness [14] }\end{array}$} & 3D simulation Android app is useful in my learning \\
\hline & 3D simulation Android app enables me to perform learning activities more quickly \\
\hline & 3D simulation Android app increases my learning productivity \\
\hline & 3D simulation Android app will increase my chances to get a better grade \\
\hline \multirow{4}{*}{$\begin{array}{l}\text { Perceived Ease } \\
\text { of Use [23] }\end{array}$} & The interaction of 3D simulation Android app is clear and understandable \\
\hline & It is easy to become skillful at using 3D simulation Android app \\
\hline & 3D simulation Android app is easy to use \\
\hline & It is easy for me to learn how to operate 3D simulation Android app \\
\hline \multirow{4}{*}{$\begin{array}{l}\text { Perceived } \\
\text { Enjoyment [21] }\end{array}$} & I believe that using 3D simulation Android app will be interesting to me \\
\hline & I believe that 3D simulation Android app will stimulate my curiosity \\
\hline & $\begin{array}{l}\text { I believe the use of 3D simulation Android app will fit well with the way } \\
\text { I like to study }\end{array}$ \\
\hline & I believe that using 3D simulation Android app can solve my problems \\
\hline \multirow{3}{*}{$\begin{array}{l}\text { Behavioral } \\
\text { Intention [14] }\end{array}$} & I intend to use 3D simulation Android app in the future \\
\hline & Given the opportunity, I will use 3D simulation Android app \\
\hline & $\begin{array}{l}\text { I plan to use 3D simulation Android app in the future } \\
\text { I predict I would use 3D simulation Android app in the future }\end{array}$ \\
\hline
\end{tabular}


Since the purposive sampling method is applied, the questionnaire was distributed to the targeted respondents from high schools located in two cities in Indonesia. Next, a preliminary analysis of the final data is addressed to examine the validity and reliability of the constructs. Component factor analysis is used to ensure the validity of all constructs, while the reliability of instruments is established using Cronbach's alpha coefficients. The final analysis is conducted by using structural equation modeling (SEM) developed in SmartPLS.

Meanwhile, the 3D simulation Android app is developed as a tool to support the study. All user interfaces are designed with the user-centered design principle proposed by Rogers et al. [24] to ensure the Android app will be user-friendly, intuitive, and interactive. The 3D simulation Android app is developed using Unity 5.6 and then packaged into an Android app.

\section{The development of research model and hypotheses}

A research model is developed based on existing studies in m-learning acceptance. Perceived Ease of Use was defined as the degree of difficulty when an individual uses m-learning [20]. The easier an m-learning application to be used by the students, the higher their intention to accept it. Many authors argued that Perceived Ease of Use effectively influences the Behavior Intention in adopting the m-learning [22], [25]. However, studies of Chao [26] and Hamidi [27] declared that the impact of Perceived Ease of Use on Behavior Intention was insignificant. Meanwhile, most studies in m-learning usage showed the high significance of Perceived Ease of Use on Perceived Usefulness, yet a study by Saroia and Gao [18] showed otherwise. Therefore, this study proposes the following hypotheses:

H1: Perceived Ease of Use significantly affects the Behavioral Intention to use m-learning (3D simulation Android app).

H2: Perceived Ease of Use significantly affects the Perceived Usefulness related to m-learning (3D simulation Android app usage).

Perceived Usefulness refers to an individual's belief that using m-learning would enhance his or her job performance [20]. Students have more willingness to accept m-learning if it offers some benefits for them. Usefulness was found to be the most significant predictor of a user's intention to use m-learning [14], [22], [25]. Another study reported there was no significant impact of Perceived Usefulness on Behavior Intention [27]. Thus, the following hypothesis is proposed:

H3: Perceived Usefulness significantly affects the Behavioral Intention to use m-learning (3D simulation Android app).

Perceived Enjoyment was defined as the degree of an individual's perception that using m-learning will be enjoyable [14]. The more enjoyable mobile learning is, the higher student's willingness to use it. The significance of Perceived Enjoyment on the 
intention of m-learning usage had been proved by several studies [14], [26]. Therefore, the following hypothesis is proposed:

H4: Perceived Enjoyment significantly affects the Behavioral Intention to use m-learning (3D simulation Android app).

Behavioral intention refers to the individual's intention to perform a specified behavior that has an effect on the actual usage [23]. Figure 1 depicts the research model used in this study which incorporates three determinants: Perceived Usefulness, Perceived Ease of Use, and Perceived Enjoyment, that may affect an individual's intention to adopt the 3D simulation Android app.

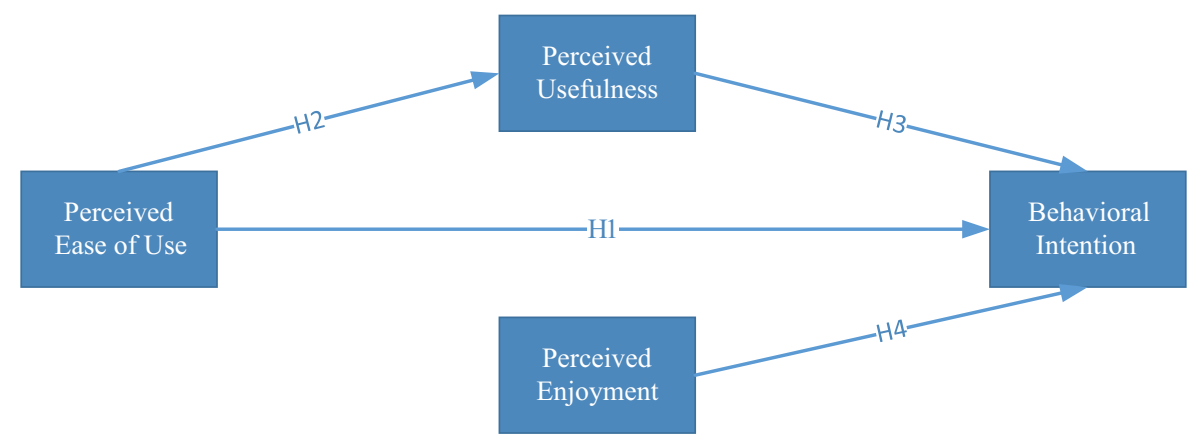

Fig. 1. Research model

\section{$5 \quad$ Results and discussion}

As the target respondents, high school students have to install the $3 \mathrm{D}$ simulation Android app on their smartphones. Students may interact with the Android app, play with the provided simulations, and immediately see the results. Next, they were given a set of tasks to perform in a certain period. After completing all tasks, they have to fill in the questionnaires through Google Forms. The total participants were 50 respondents, 32 males, and 18 females.

Table 2 shows that the validity of all constructs is satisfactory since all loading values are above 0.4, based on Straub et al. [28] guidelines. The Cronbach's alpha values of all variables also exceeded the acceptable value of 0.7 , following the guidelines from George and Mallery [29]. In addition, both composite reliability (CR) and average variance extracted (AVE) are computed to check the composite reliability and convergent validity of each latent variable. The result shows that the values of CR are greater than the minimum threshold values of 0.7 , and all AVE values for all the latent variables are also above 0.5, as suggested by Fornell and Larcker [30]. 
Table 2. Validity and reliability result

\begin{tabular}{|c|c|c|c|c|c|c|}
\hline Variable & Indicator & Loading & Cronbach $\alpha$ & Result & CR & AVE ( $\sqrt{ }$ AVE) \\
\hline \multirow[t]{4}{*}{ Perceived Enjoyment } & PE2 & 0.857 & \multirow{4}{*}{0.890} & \multirow{4}{*}{ Good } & \multirow{4}{*}{0.923} & \multirow{4}{*}{$\begin{array}{c}0.751 \\
(0.866)\end{array}$} \\
\hline & PE1 & 0.852 & & & & \\
\hline & PE4 & 0.885 & & & & \\
\hline & PE3 & 0.871 & & & & \\
\hline \multirow[t]{4}{*}{ Perceived Usefulness } & PU2 & 0.872 & \multirow{4}{*}{0.869} & \multirow{4}{*}{ Good } & \multirow{4}{*}{0.911} & \multirow{4}{*}{$\begin{array}{c}0.718 \\
(0.847)\end{array}$} \\
\hline & PU3 & 0.872 & & & & \\
\hline & PU4 & 0.811 & & & & \\
\hline & PU1 & 0.832 & & & & \\
\hline \multirow[t]{4}{*}{ Perceived Ease of Use } & PEU3 & 0.824 & \multirow{4}{*}{0.834} & \multirow{4}{*}{ Good } & \multirow{4}{*}{0.887} & \multirow{4}{*}{$\begin{array}{c}0.664 \\
(0.815)\end{array}$} \\
\hline & PEU2 & 0.895 & & & & \\
\hline & PEU4 & 0.796 & & & & \\
\hline & PEU1 & 0.737 & & & & \\
\hline \multirow[t]{4}{*}{ Behavioral Intention } & $\mathrm{BI} 2$ & 0.814 & \multirow{4}{*}{0.840} & \multirow{4}{*}{ Good } & \multirow{4}{*}{0.891} & \multirow{4}{*}{$\begin{array}{c}0.671 \\
(0.819)\end{array}$} \\
\hline & BI4 & 0.763 & & & & \\
\hline & BI1 & 0.811 & & & & \\
\hline & $\mathrm{BI} 3$ & 0.884 & & & & \\
\hline
\end{tabular}

Next, to ensure the model variables can be analyzed using SEM, this study performs the descriptive data analyses. Based on the results presented in Table 3, all variables are satisfactory since the values of the magnitudes of skewness and kurtosis for all indicators are within the acceptable limits of 3 and 7, respectively, following Kline [31] criteria.

Table 3. Descriptive statistics

\begin{tabular}{|l|c|c|c|c|c|c|c|}
\hline Indicator & Mean & Median & Min & Max & Stand Dev & Kurtosis & Skewness \\
\hline PE1 & 4.020 & 4.000 & 2.000 & 5.000 & 0.707 & 0.132 & -0.380 \\
\hline PE2 & 4.180 & 4.000 & 3.000 & 5.000 & 0.517 & 0.296 & 0.221 \\
\hline PE3 & 3.900 & 4.000 & 3.000 & 5.000 & 0.640 & -0.525 & 0.094 \\
\hline PE4 & 4.040 & 4.000 & 3.000 & 5.000 & 0.599 & -0.114 & -0.015 \\
\hline PU1 & 4.400 & 4.000 & 4.000 & 5.000 & 0.490 & -1.900 & 0.421 \\
\hline PU2 & 4.220 & 4.000 & 3.000 & 5.000 & 0.642 & -0.623 & -0.243 \\
\hline PU3 & 3.980 & 4.000 & 3.000 & 5.000 & 0.678 & -0.783 & 0.025 \\
\hline PU4 & 3.860 & 4.000 & 3.000 & 5.000 & 0.600 & -0.249 & 0.067 \\
\hline PEU1 & 4.020 & 4.000 & 3.000 & 5.000 & 0.510 & 1.065 & 0.034 \\
\hline PEU2 & 3.880 & 4.000 & 3.000 & 5.000 & 0.621 & -0.389 & 0.088 \\
\hline PEU3 & 4.020 & 4.000 & 2.000 & 5.000 & 0.648 & 1.016 & -0.475 \\
\hline PEU4 & 4.000 & 4.000 & 3.000 & 5.000 & 0.600 & -0.116 & 0.000 \\
\hline BI1 & 4.420 & 4.000 & 3.000 & 5.000 & 0.533 & -1.156 & -0.078 \\
\hline BI2 & 4.080 & 4.000 & 3.000 & 5.000 & 0.523 & 0.729 & 0.100 \\
\hline BI3 & 4.260 & 4.000 & 3.000 & 5.000 & 0.482 & -0.371 & 0.563 \\
\hline BI4 & 4.260 & 4.000 & 3.000 & 5.000 & 0.522 & -0.300 & 0.217 \\
\hline
\end{tabular}


T-tests are used to investigate whether there are significant differences between the mean values of a latent variable and the neutral value of 3 . The result indicates that all mean values are above the neutral value of 3 at a level of 0.05 or less. Furthermore, the fit statistics of the research model show that the variance of the intention to adopt a $3 \mathrm{D}$ simulation mobile app is $48.5 \%$ that indicates good explanatory power.

Table 4 presents the result of the hypotheses. The shaded cells correspond with the three supported hypotheses. Perceived Enjoyment significantly influences the student's intention at a level of $0.001(* * *)$. It means that students are willing to use the $3 \mathrm{D}$ simulation Android app only if they enjoy using it. This finding aligns with a study conducted by Pramana [14] and Chao [26]. Perceived Usefulness also significantly influences the intention to use the 3D simulation Android app at a level of $0.05(*)$, which supports several prior studies [14], [22], [25]. Surprisingly, Perceived Ease of Use does not significantly impact the Behavioral Intention at a level of 0.05 or less. This means that high school students place less importance on Perceived Ease of Use as a motivation for accepting 3D simulation Android app. One factor that we argue might influence this result is the behavior of Generation $\mathrm{Z}$ students, which are already familiar with technologies from their youth days [7], so they can use complex Android app. This result fits with Chao's and Hamidi's studies [26], [27]. However, the outcome might be different if the 3D simulation Android app users are more general, not limited to Generation Z students only. Another finding proves the influence of Perceived Ease of Use on Perceived Usefulness at a level of $0.01(* *)$ as many other studies have proven this hypothesis.

Table 4. Hypotheses test

\begin{tabular}{|l|l|c|c|c|c|c|c|}
\hline \multicolumn{2}{|c|}{ Hypothesis } & $\begin{array}{c}\text { Original } \\
\text { Sample }\end{array}$ & $\begin{array}{c}\text { Sample } \\
\text { Mean }\end{array}$ & $\begin{array}{c}\text { Stand } \\
\text { Dev }\end{array}$ & $\begin{array}{c}\text { T } \\
\text { Statistics }\end{array}$ & P Values & Decision \\
\hline H1 & PEU $\rightarrow$ BI & $-0,155$ & $-0,149$ & 0,155 & 0,997 & 0,319 & Rejected \\
\hline H2 & PEU $\rightarrow$ PU & 0,345 & 0,366 & 0,116 & 2,961 & 0,003 & Accepted \\
\hline H3 & PU $\rightarrow$ BI & 0,308 & 0,310 & 0,122 & 2,523 & 0,012 & Accepted \\
\hline H4 & PE $\rightarrow$ BI & 0,529 & 0,530 & 0,109 & 4,837 & 0,000 & Accepted \\
\hline
\end{tabular}

\section{Conclusion}

The study finds that Perceived Enjoyment is the strongest factor influencing the student's intention to use the 3D simulation Android app, followed by Perceived Usefulness. Surprisingly, the Perceived Ease of Use factor does not significantly affect the acceptance of the 3D simulation Android app. This study concludes that high school students are willing to adopt the 3D simulation Android app since it can help them in learning physics (Usefulness) by working on the problems and playing with the simulations (enjoyment). Besides having theoretical contribution, this study is expected to have a practical contribution to mobile app developers (especially Android app) who want to develop an educational app for mobile learning. They have to provide the students with useful mobile app content and 3D simulation to make an enjoyable mobile app for students to complement their studies. 


\section{$7 \quad$ Limitations and future research}

There are some limitations to this study. This study is conducted in Indonesia with all respondents from Indonesia, so the findings may not apply to other countries nor education in general. Due to the limited number of respondents (50 respondents), further study may be needed with more respondents and different groups of respondents, which can yield different results. Future research may add some other constructs in the theoretical model to increase the explanatory power.

\section{$8 \quad$ References}

[1] Datareportal, "Digital in Indonesia: All the Statistics You Need in 2021-DataReportal Global Digital Insights.” https://datareportal.com/reports/digital-2021-indonesia (accessed Apr. 15, 2021).

[2] detikInet, "Riset: Ada 175,2 Juta Pengguna Internet di Indonesia," 2020. https://inet.detik. com/cyberlife/d-4907674/riset-ada-1752-juta-pengguna-internet-di-indonesia (accessed Apr. 23, 2021).

[3] 42matters, "Indonesia App Market Statistics in 2021." https://42matters.com/indonesia-app-market-statistics (accessed Apr. 23, 2021).

[4] S. K. Prof and B. G. Prof, "Design and assessment of using smartphone application in the classroom to improve students' learning," in International Journal of Engineering Pedagogy, 2019, vol. 9, no. 2, pp. 17-34. doi: https://doi.org/10.3991/ijep.v9i2.9764

[5] S. Papadakis, M. Kalogiannakis, and N. Zaranis, "Teaching mathematics with mobile devices and the Realistic Mathematical Education (RME) approach in kindergarten," Advances in Mobile Learning Educational Research, vol. 1, no. 1, pp. 5-18, 2021, doi: https://doi.org/10.25082/AMLER.2021.01.002

[6] A. Al-Amri, M. Osman, and A. al Musawi, "The effectiveness of a 3D-virtual reality learning environment (3D-VRLE) on the omani eighth grade students' achievement and motivation towards physics learning," International Journal of Emerging Technologies in Learning, vol. 15 , no. 5, pp. 4-16, 2020, doi: https://doi.org/10.3991/ijet.v15i05.11890

[7] A. Turner, "Generation Z: Technology and Social Interest," The Journal of Individual Psychology, vol. 71, no. 2, 2015, doi: https://doi.org/10.1353/jip.2015.0021

[8] R. Papp and E. Matulich, "Negotiating the deal : using technology to reach the Millennials," Journal of Behavioral Studies in Business, vol. 4, no. May, pp. 1-12, 2011, [Online]. Available: http://mobile.www.aabri.com/manuscripts/111063.pdf

[9] L. Xiao, "Animation Trends in Education," International Journal of Information and Education Technology, pp. 286-289, 2013, doi: https://doi.org/10.7763/IJIET.2013.V3.282

[10] M. Alrasheedi and L. F. Capretz, "Determination of critical success factors affecting mobile learning: A meta-analysis approach," Turkish Online Journal of Educational Technology, vol. 14, no. 2, pp. 41-51, 2015, Accessed: Jun. 23, 2021. [Online]. Available: https://www. researchgate.net/publication/274696222_Determination_of_Critical_Success_Factors Affecting_Mobile_Learning_A_Meta-Analysis_Approach

[11] I. Reisoğlu, B. Topu, R. Yılmaz, T. Karakuş Yılmaz, and Y. Göktaş, "3D virtual learning environments in education: a meta-review," Asia Pacific Education Review, vol. 18, no. 1, pp. 81-100, Mar. 2017, doi: https://doi.org/10.1007/s12564-016-9467-0

[12] Y. S. Wang, M. C. Wu, and H. Y. Wang, "Investigating the determinants and age and gender differences in the acceptance of mobile learning," British Journal of Educational Technology, vol. 40, no. 1, pp. 92-118, Jan. 2009, doi: https://doi.org/10.1111/j.1467-8535.2007.00809.x 
[13] Helen Crompton, "A historical overview of mobile learning: Toward learner-centered education.," in Handbook of Mobile Learning, 2013.

[14] E. Pramana, "Determinants of the Adoption of Mobile Learning Systems Among University Students," Journal of Information Technology Education Research, vol. 17, pp. 365-398, 2018. https://doi.org/10.28945/4119

[15] K. F. Hashim, F. B. Tan, and A. Rashid, "Adult learners' intention to adopt mobile learning: A motivational perspective," British Journal of Educational Technology, vol. 46, no. 2. 2015. doi: https://doi.org/10.1111/bjet.12148

[16] S. Hao, V. P. Dennen, and L. Mei, "Influential factors for mobile learning acceptance among Chinese users," Educational Technology Research and Development, vol. 65, no. 1, 2017, doi: https://doi.org/10.1007/s11423-016-9465-2

[17] F. Aburub and I. Alnawas, "A new integrated model to explore factors that influence adoption of mobile learning in higher education: An empirical investigation," Education and Information Technologies, vol. 24, no. 3, 2019, doi: https://doi.org/10.1007/s10639-019-09862-x

[18] A. I. Saroia and S. Gao, "Investigating university students' intention to use mobile learning management systems in Sweden," Innovations in Education and Teaching International, vol. 56, no. 5, 2019, doi: https://doi.org/10.1080/14703297.2018.1557068

[19] S. Papadakis, "Evaluating pre-service teachers' acceptance of mobile devices with regards to their age and gender: A case study in Greece," International Journal of Mobile Learning and Organisation, vol. 12, no. 4, pp. 336-352, 2018, doi: https://doi.org/10.1504/ IJMLO.2018.095130

[20] F. D. Davis, "Perceived usefulness, perceived ease of use, and user acceptance of information technology," MIS Quarterly: Management Information Systems, vol. 13, no. 3, pp. 319-339, 1989, doi: https://doi.org/10.2307/249008

[21] S. I. Senaratne and S. M. Samarasinghe, "Factors Affecting the Intention to Adopt M-Learning," International Business Research, vol. 12, no. 2, 2019, doi: https://doi.org/ 10.5539/ibr.v12n2p150

[22] A. S. Al-Adwan, A. Al-Adwan, and H. Berger, "Solving the mystery of mobile learning adoption in higher education," International Journal of Mobile Communications, vol. 16, no. 1, 2018, doi: https://doi.org/10.1504/IJMC.2018.088271

[23] L. Lisana, "Factors influencing the adoption of mobile payment systems in Indonesia," International Journal of Web Information Systems, vol. ahead-of-print, no. ahead-of-print, Apr. 2021, doi: https://doi.org/10.1108/IJWIS-01-2021-0004

[24] J. Preece, H. Sharp, and Y. Rogers, Interaction Design: Beyond Human-Computer Interaction, 4th ed. Wiley, 2015.

[25] M. Kalogiannakis and S. Papadakis, "Evaluating pre-service kindergarten teachers' intention to adopt and use tablets into teaching practice for natural sciences," International Journal of Mobile Learning and Organisation, vol. 13, no. 1, 2019, doi: https://doi.org/10.1504/ IJMLO.2019.096479

[26] C. M. Chao, "Factors determining the behavioral intention to use mobile learning: An application and extension of the UTAUT model," Frontiers in Psychology, vol. 10, no. JULY, 2019, doi: https://doi.org/10.3389/fpsyg.2019.01652

[27] H. Hamidi and A. Chavoshi, "Analysis of the essential factors for the adoption of mobile learning in higher education: A case study of students of the University of Technology," Telematics and Informatics, vol. 35, no. 4, 2018, doi: https://doi.org/10.1016/j.tele.2017.09.016

[28] D. Straub and D. Gefen, "Validation Guidelines for IS Positivist Research," Communications of the Association for Information Systems, vol. 13, 2004, doi: https://doi. org/10.17705/1CAIS.01324

[29] D. George and P. Mallery, SPSS for Windows Step by Step: A Simple Study Guide and Reference, 17.0 Update, 10th ed. USA: Allyn \&amp; Bacon, Inc., 2009. 
[30] C. Fornell and D. F. Larcker, "Evaluating Structural Equation Models with Unobservable Variables and Measurement Error," Journal of Marketing Research, vol. 18, no. 1, 1981, doi: https://doi.org/10.2307/3151312

[31] R. B. Kline, Principles and practice of structural equation modeling. Guilford publications, 2015.

\section{Authors}

Lisana Lisana is a lecturer at the Department of Informatics, University of Surabaya, Indonesia. She is a PhD candidate at Vincent Mary School of Science and Technology, Assumption University, Thailand. She got a Bachelor degree in Computer Science from Sekolah Tinggi Teknik Surabaya, Indonesia and a Master degree in Information Technology from Swinburne University, Australia. Email: lisana@staff.ubaya.ac.id.

Marcellinus Ferdinand Suciadi is a Lecturer at the Department of Informatics, University of Surabaya, Indonesia. He was graduated from the same department and continued his study at the School of Computing, National University of Singapore, Singapore. Email: ferdi@staff.ubaya.ac.id.

Article submitted 2021-05-04. Resubmitted 2021-07-04. Final acceptance 2021-07-06. Final version published as submitted by the authors. 